\title{
KÖNYVJELZÖ
}

\section{MEZEI ISTVÁN: VÁROSOK SZLOVÁKIÁBAN ÉS A MAGYAR HATÁR MENTÉN}

\author{
(Fórum Kisebbségkutató Intézet - MTA RKK, Somorja - Pécs, \\ 2008,175 o.)
}

\section{FARKAS GYÖRGY}

Hogyan „...mentődött át” Szlovákia városainak „...hajdani társadalmi, nyelvi, kulturális, vallási, emberi sokszínűség[e] ... a vérzivataros évtizedeken?” - teszi fel dolgozata előszavában a ,legnagyobb ... múltból itt maradt kérdést” a szerző, hogy aztán müve több mint 160 - adatokkal, táblázatokkal, térképekkel sürün teletűzdelt - oldalán átvezetve olvasóit, bárki bátran levonhassa a munka tételesen ki nem mondott, tömören összefoglalható fő következtetését: sehogy sem... Nehezen vitatható tény, hogy szinte semmi nem mentődött át a 18.-19. században gyökerező városfejlődés jellemző etnikai tarkaságából a 21. század elejére. Nemcsak a statisztika felhalmozott adatainak tömege, de a megélt ,valóság” is, az egyszerü, hétköznapi, az emberek együttélése során átélhető, begyüjthető tapasztalatok tömkelege támaszthatja alá nap mint nap a Szlovákia városainak múltjában tájékozottabb kutatók szomorkás konklúzióját. A felismerés persze nem új keletü. Már az előszóban ,tényként, tanulságként” állapítja meg maga a szerző is, hogy a Felvidékből létrehozott „teljesen új” államon belül egy új városszerkezet, ,....saját maguk alkotta regionális egységek alakultak ki”, mégpedig - s ez könyve egyik vezérfonala - egy sikeres, az újkori szlovák nemzet tagjainak munkálkodása révén véghezvitt „honfoglalás” [k. t.] révén.

Célkitüzéseiben ez a dolgozat elsősorban a „régi és az új összevetésével” igyekszik „,bemutatni a megváltozott viszonyokat”, majd végül, némiképp derüsebbre hangszerelve a munka lezárását ,....az együttmüködés végre újból benépesülő tereit járja be”. Mindezzel a szerző abbéli, feltétlenül dicséretes törekvését igyekszik valóra váltani, hogy megértse és bemutassa az európai uniós csatlakozások után kiteljesedni remélt, a hangzatos politikai állásfoglalások szerint is görcsmentessé alakítható határ menti együttmüködések hátterét, mozgatórugóit, lehetséges formáit és esetleges akadályait.

A szerzőnek a munka címében is tükröződő véleménye kutatása tárgyáról, miszerint a „,.. szlovák városszerkezet egésze felől kell a határ menti városokat megközelíteni és értelmezni” kétségtelenül helytálló, ugyanakkor - véleményem szerint - egy jellegzetesen magyar, vagy még pontosabban: „,magyarországi” szemlélet-mód gyümölcse. A szöveget egyébként is áthatja valamiféle üdítő - nem találok rá jobb kifejezést - „magyarországi” könnyedség. Arra gondolok, hogy egy szlovákiai magyar szerző, 
vagy a szlovákiai tudományos élet belső „,hangütéseit” közvetlenebbül érzékelő kutató sokkal „hamarabb” észleli, ha kibeszélhetetlen tabutémákhoz közelít, s nem von le olyan könnyen és határozottan - magyar szemszögböl - problémátlan és „szívderengető" konklúziókat, mint ezt egy - mindezen görcsöket legfeljebb hallomásból ismerő - „magyarországi” szocializációjú kollégája. Ugyanakkor azt is megjegyezném, hogy a szerző ezen jellegzetes, és egyébként is természetesnek tekinthető szemléletü közelítése híján van bármiféle hamis vagy irritáló fölényérzetnek, ami a múlt „magyar” értelmezése elutasításának mondhatni szokásos és sajnos, nem egy esetben, megalapozott oka a szlovák fél részéről. Az általam - eléggé leegyszerüsítően „magyarországinak” bélyegzett szemlélet megjelenésére egy konkrét példa: a szerző az első csehszlovák államalapítás főváros-dilemmáinak korrekt ismertetése (60. o.) után, a közigazgatás városhálózat szervező módszerként való bemutatása során enyhén megkérdőjelezni látszik Pozsony újkori fővárosi rangját. „Pozsony fővárossá válásának rögös útja, a rendre fölmerülő viták mutatják, hogy az 1993-ban önállóvá vált friss államnak még a fơvárosát is el kellett fogadtatnia." (95-96. o., k. t.) Az idézett mondat talán kissé homályos: nem világos, és a szövegkörnyezetből sem derül ki igazán, hogy kivel kellett Pozsony fővárosi rangját elfogadtatni. A nemzetközi diplomácia terén talán lehettek nehézségek. Azonban az önállóvá lett Szlovákia esetleges főváros-váltása, vagy az akkorra is már csaknem félmilliós, „egyetlen metropolisz” hazai városhálózatbeli vagy esetleges nemzetközi szerepének megkérdőjelezése a korabeli közvéleményben nemcsak, hogy a lehetetlenség határát súroló fikció lett volna - szlovák szemszögből -, de tényszerüen sem állja meg a helyét; igazán komoly társadalmi, politikai vita a fővárosról 1993-ban nem volt, fel sem merült. Szlovák részről mindez úgy hat, mintha - egy a magyar történelmet jól ismerő osztrák - értekezne arról, hogy Magyarország fővárosa tulajdonképpen akár Székesfehérvár vagy éppen Debrecen is lehetne.

A szlovákiai városok múltbeli multikulturális jellegének értékelése a dolgozatban szintén ebből a szemléletből ered. Mezei abnormálisnak látja és láttatja azt, ami abnormális - magyar szemszögből -: a Magyar Királyság hajdani koronázó városában, az országgyűlések városában, az újkori magyar nemzet történetéhez ezer szállal kötődő Pozsonyban a 20. század végén kevesebb német és magyar nemzetiségü, anyanyelvü, kötődésü polgár él, mint a század elején (... és a „,kevesebbel” még nagyon-nagyon erősen túloztam...). Aki Szlovákiában él, ott nőtt fel, lett ilyen-olyan szinten iskolázott emberré, az tudja, hogy - pár, mutatóban megmaradt „,pressburgert”, illetve pressburgerségére-prešporčanságára büszke értelmiségi kiteljesedésének áramában ráébredő pozsonyi szlovák-tudatú, -nyelvü entellektüelt leszámítva - EZ tekintendő normálisnak! Ez volt a csillagokban megírva, nem is lehetett másképp. S tudjuk jól, ez az egynemüsítés-egynemüsödés a mai Magyarország városaiban is lezajlott, más irányban persze, és másképpen is, talán elég csak a hajdani fővárosok, majd az egyesített Budapest példájára utalni; ,elveszett” itt is pár tízezernyi lélek - ezúttal a képzeletbeli „,szlovák serpenyőből”. Az más kérdés, hogy ma Magyarországon azért illő és üdvös keseregni e fordulat fölött; kárhoztatni, legalább kicsikét, mint örökre elveszett lehetőséget... S ez az őszinte veszteségérzet 
hatja át Mezei közelítését is e témához, amit, hangsúlyozandó, a túloldalon munkálkodó szerzők fölöttébb ritkán értékelnek másnak, mint álságosnak és képmutatónak, és tán ezért is meglehetősen hanyagolják. Mindenesetre a könyv befejező részében több helyütt nagyon érzékletesen összefoglalt saját tapasztalatai szerint ezekkel a gyakorlatilag áthidalhatatlan szemléletbeli különbségekkel Mezei is tisztában van, hiszen a határokon átnyúló együttmüködés fontos szereplőjeként, alakítójaként a folyamatok napi gyakorlatában sokféle formában szembesülnie kellett velük (161. o. skk.). Az általa hivatkozott, szlovák szerzőktől feldolgozott szakirodalom azonban túlnyomórészt angol nyelvü, s ez mégiscsak inkább meghatározza a dolgozat egyébként higgadt tényszerűségre törekvő alapjait, mint a személyes élmények. A közvetítő nyelv szürőjén ezek a hangsúlyok, árnyalatok, érthetően, „nem jönnek át”, vagy eleve meg sem jelennek; miközben a szlovákiai oldal „belső” kommunikációját, diskurzusait az ottani, folytonosan formált, alakuló közmegegyezéseik kereteit, mindmáig nagyon erőteljesen jellemzik és áthatják.

A hét fejezetre tagolt munka tulajdonképpen két (három?) témakört ölel fel.

Az első témakör (III.-V. fejezetek) Szlovákia mai területének településtörténetéből a városok fejlődését fogja át, hangsúlyosan a 18. századtól lezajlott történésekre, különösen a városok népességfejlődésére, a közigazgatási pozícióik változására, valamint a településhierarchiabeli rangjuk alakulására összpontosítva, külön fejezetet szentelve az 1993 utáni fejleményeknek. A munka második vizsgált témaköre (VII. fejezet) a szlovák-magyar határ menti együttmüködés; itt azonban némi törés érzékelhető a tekintetben, hogy a határ mente szlovákiai városainak (,,városvonalnak") meglehetősen szükre szabott ismertetése (141-145. o.) mellett az együttmüködés formáinak, lehetőségeinek részletesebb ismertetésénél már egyáltalán nem a településeken van a hangsúly. Mintha nem kapcsolódna hézagmentesen a dolgozat két fő része, miközben a „Szándékos regionalizálás - szerves regionalizálódás” címet viselő VI. fejezet nagy valószínüséggel éppen a két fő témakör közötti átkötés megteremtését szolgálná.

Úgy vélem azonban, hogy a jól kirajzolódó két fő rész, kutatási témakör mellett kimutatható még egy harmadik, szerkezetileg nem azonosítható, az utalások, a fogalomhasználat gyakorisága, szövegbéli előfordulásai alapján azonban a szerző által legalább ennyire hangsúlyosan kezelt - s a föntebb már jellemzett előszóban is rögvest előforduló - kérdéskör: a 20. századi „szlovák honfoglalás” [k. t.] tézise. Azt hiszem, mindnyájan azonnal értjük, mi az, amire ezzel a szóval Mezei rámutat, mi az, amit ezzel a fogalomhasználattal megragadni törekszik. (Jó, persze, azért legalább egy történelem-érettségi, magyar nyelven, kell hozzá...) A történtek ilyesféle értelmezése azonban olyannyira idegen a szlovák közéletben, hogy még csak le sem fordítható - legföljebb körülírni lehet(ne); a modern szlovák irodalmi nyelvben tudtommal nem alkottak a magyar „honfoglalás” szavunknak nagyjából megfelelő értelmü szót. Talán itt érhető tetten a legjobban a két szemlélet, a kétféle közelítés különbsége: ami az egyik oldalon különösebb kérdésfölvetés-mentes egyöntetűség, a másikon még csak meg sem nevezhető, emészthető, érthető probléma. Pontosabban; érteni azért értik, de csak fölöttébb ingerlő provokációként. Igazán kíváncsi 
vagyok, miként fordították ezeket a részeket szlovákra. Félreértés ne essék: nemcsak értem Mezei szóhasználatát, hanem indokoltnak, igaznak és hitelesnek - megélhetőnek - is tartom. De tudom azt is, hogy e téren nincs esély - még egy darabig - a kompromisszumra. Talán, majd ha a mai magyarországi szlovák kisebbség szintjére sorvad a szlovákiai magyar közösség politikai, közéletbeli (gazdasági; olyan szinte nincs is, amint ez a munka is jelzi...) súlya, majd akkor megbeszélhetö lesz ez a dolog, vitaalapként értelmezhetők lesznek a szlovákiai városok népességének nemzetiségi megoszlásában bekövetkezett változásokat tükröző adatsorok, e módon is. Azért egyelöre tekintettel kell még lenni arra, hogy ez egy folyamatban lévő ügy, legfeljebb a remélt/rettegett végkifejlet kezd már sokak szeme elött, egyre gyorsuló ütemben felsejleni...

Alkalmazott módszereiben a dolgozat nem hoz újat; a szerző a szlovákiai városfejlődés főbb fejleményeinek ismertetését és a szlovák „honfoglalás”-tézis alátámasztását a lelkiismeretesen összegyüjtött, hozzáférhető adatok alapszintü statisztikai elemzése, csoportosítása és megjelenítése révén kísérli meg.

A munka néhány részletével kapcsolatban lenne vitázó észrevételem. Az első, elismerem, meglehetősen szubjektív. Igazán komoly érvekkel alátámasztani nem tudom; de remélem, hogy mégsem hat fölösleges kötözködésnek, talán még akkor sem, ha elörebocsátom; a szerző e téren kialakított álláspontját semmiképp sem tartom hibásnak vagy tévesnek: mindössze arról van szó, hogy egy bizonyos csoportosítás esetében más megoldást alkalmaztam volna. A „Felvidék városai 1918 elött” címü III. fejezetben az első világháborúig kialakult városhálózat népességszámának és nemzetiségi összetételének jellemzésénél a szerző az 1861. évi, korabeli szlovák politikusok és értelmiségiek által megfogalmazott, s a szlovák nemzet újkori történetében elsőként konkrét területi elkülönülés mellett kardoskodó „Memorandum”-ban megnevezett megyék és a 20. század végi Szlovákia városait hasonlítja össze. A 27. oldalon található 4. és 5. táblázat az 1910. évi magyarországi népszámlálásnak az etnikai összetételre vonatkozó adatsorait elemzi és veti össze a 2001. évi szlovákiai népszámlálás vonatkozó adatsoraival, illetve az összehasonlítás eredményeit elemzi és foglalja össze a 26-30. oldalakon a 4. és 6. táblázatban. Magát az ötletet, hogy a memorandumban elöször körvonalazódó területet tekintsük egyfajta kiindulási alapnak vagy keretnek, és ez alapján vonjuk meg a kiegyezés korától a 21. század hajnaláig terjedő változások ívének mérlegét a munka vizsgált témaköreiben, tehát a „megvalósult” Szlovákiabeli városok népességének egy évszázadnyi változásában, nemzetiségi összetételük átalakulásában, nagyon jónak és fölöttébb célszerünek tartom. Az ötlet megvalósításánál azonban rugalmasabban jártam volna el. A szerző a két táblázatban a városokat - egyébként nagyon is helyeselhetően - „északi” és „déli” csoportokra osztja, mert helyesen ismeri fel, hogy a memorandum alkotói az általuk elképzelt területegység kapcsán „Legtisztább szláv vármegyékröl írtak és a magyar többségü vármegyéket vegyes nemzetiségünek mondták" (29. o., k. t.). Hozzátenném: ez a logika és ez a gyakorlat Szlovákiában máig tetten érhetö. Nos, a felosztás és a külön összehasonlítás fölöttébb indokolt, azonban a memorandumbéli, korabeli vármegyei beosztáshoz való merev ragaszkodás 
miatt olyan városok kerültek a ,déli” csoportba, mint Dobsina, Körmöcbánya, Korpona vagy Selmecbánya. Utóbbi kettőről nyilván lehet vitatkozni, de az első kettőnek „déli” felvidéki városként való szerepeltetése szemet szúró. Legalábbis számomra „földrajzilag” elég nehezen emészthető. A korabeli Felvidék déli, részben még magyar többségü sávjától, az akkori nyelvhatártól jelentős távolságban északra fekszik mindkét település, s noha akkortájt az észak-déli kapcsolatok és összeköttetések a mainál lényegesen erősebbek és fontosabbak voltak, mindkettő inkább kötődött már akkor is szűkebb szomszédsága városaihoz. Tehát sem földrajzilag, sem pedig településszerkezetbeli helyzetüket illetően nem helyénvaló egyikük esetében sem a „déli” jelző: pusztán a korabeli politikai földrajzi viszonyokhoz való ragaszkodás alapján kerültek besorolásra. Ez annál is inkább feltűnő, mivel a szerző által bizonyítani kívánt tézis, a déli rész városainak ezidőtájt még erősen magyar vagy legalábbis nem szlovák arculata és annak nagy átalakulása az ezredfordulóra, véleményem szerint a bizonyításhoz használt csoportosítási eljárásnál sokkal szembetünőbb számsorokat és összesített értékeket eredményezhetett volna, ha az összehasonlításnál célszerübben nem a megyei, hanem a memorandum-korabeli járási közigazgatási beosztást veszi alapul.

Az V. fejezet („Szlovákia városai 1993 után”) első kétharmada az új állam városhálózatával foglalkozik, közülük az első alfejezet a geopolitika hatását vizsgálja a városhálózatra (90-95. o.). Noha a fejezettel, tartalmilag, nem vitáznék, néhány észrevételem azért lenne. A szerző gondolatmenete a munka ezen részében mindössze három szlovák szerző tanulmányaira támaszkodik, legalábbis a hivatkozások szerint. Az egyik magyar fordításban jelent meg, a másik kettő angol nyelven, utóbbiak közül azonban az egyik - címe szerint is - hangsúlyosan inkább csak Pozsony helyzetére fókuszál. Úgy vélem, a szerzőnek a fejezetben kifejtett egyik megállapítása legalábbis kiegészítésre szorul. A 93. oldalon írja: „A kelet-nyugati irányultság kiemelkedő fontosságú a szlovák politika és közélet számára, amit kifejez, hogy önmagukat Kárpáti-országnak tekintik” [k. t.]. Nos, éppen Pozsony „,birtoklása" az, ami fölöttébb fontossá teszi - szlovák szemszögböl -, hogy országuk „kárpáti” (értsd: döntően hegyvidéki) jellegének felmutatása mellett, annak dunai karakterét is kidomborítsák. A két jelző, kart karba öltve számtalan helyen, legmélyrehatóbban mégis a földrajztankönyvek oldalain, erősen kihangsúlyozva, nagyon sok helyről volna idézhető. A mondatbéli állítást némileg módosítva tehát leszögezném: a szlovákok önmagukat inkább kárpáti-dunai országnak tekintik ( ,karpatsko-dunajská vlast”). Szlovákia tájbeosztásának taxonómiai rendszere mellett még legalább egy, számomra ismeretlen eredetü, de sokszor, sokféle formában és helyen hallott-olvasott mondatfoszlányra, talán afféle szállóigére hivatkoznék itt: „Od Tatier k Dunaju”, vagyis: a Tátrától a Dunáig [...terjed a szlovák haza]! (Például egészen biztos, hogy a nyolcvanas évek közepén-végén, egy akkori pozsonyi rockegyüttes egyik korabeli slágerének a refrénje is ez volt.)

Végül, amit még ebből a fejezetből hiányolok, ha már a geopolitika is a téma feldolgozásának felvállalt szempontjai közé került; az 1938. évi első bécsi döntés következményeinek, s a belőle számukra levonható, a szlovák közéletbe leszürődő 
és máig ható tanulságoknak a jelzése legalább. Jelesül a déli, „magyarlakta” területek ,elvesztésének” félelme-fóbiája, ha már egyebekben a munka figyelemreméltó őszinteséggel írja le, például a ,szlovák honfoglalást”. Ez a fóbia ugyanis - kimondatlanul, kimondhatatlanul - ott rejlik a szlovákiai magyarok legtöbbjének őszinte meggyőződése szerint is, a déli, határ menti területeknek a többség részéről megnyilvánuló kezelésében, a több mint ellentmondásos „fejlesztésükben”, például. Tetten érhető az itteni városok helyzetének alakulásában és alakításában is, amint azt a könyv is nagyon érzékletesen leírja, és - ha természetesen nem is bizonyíthatja az említett sejtéseket -, de legalábbis megmagyaráz sok, e téren tapasztalható furcsaságot.

A feldolgozott téma feltétlenül gondosabb szerkesztést érdemelt volna. Néhány apróbb elütés, hiányzó betü (pl. 146., 164., 165. o.), névelő (125. o.), helyenként, föleg a szöveg másik felében kifésületlen maradt, de sajnos az apró bakik mellett néhány fajsúlyosabb javítanivaló is akad. A 69. o. utolsó bekezdésének második mondata értelmetlen, valószínűleg befejezetlen maradt. Ugyanezen az oldalon az ipar fellegvárainak leírásánál több említett település neve (pl. Garamnémetfalva; Cégely; Detrekőcsütörtök; Ötösbánya) sem szerepel a munka végéhez csatolt kétnyelvü településnév-függelékben. Sajnos, egyikükről sem állíthatnánk, hogy közismertségnek örvendene a mai magyar nyelvhasználók körében; már csak ezért is ott lenne a helyük az egyébként dicsérendő figyelmességgel csatolt névjegyzékben. A 113. oldalon található 34. táblázatban, amely az ipari és a szolgáltató vállalatokat veti össze néhány kiválasztott településen, nincs megadva, hogy a „,bevétel” miben értendő, bár ez még kikövetkeztethető lenne, de nincs utalás arra sem, melyik évre vonatkoznak az adatok. A táblázat utolsó oszlopának jelzése (,\%”) sem igazán szerencsés; igazából csak a szöveg teszi könnyebben és egyértelműen „emészthetővé” a táblázat számsorait. Részben szerkesztésbeli figyelmetlenségnek tudható be az is, hogy a 142. oldalon, az adott szövegkörnyezetbe ágyazva, zavaróan elözmény nélkül bukkan elő, hivatkozott példaként a Hídverő társulás, miközben a szerveződés alaposabb ismertetése a dolgozat utolsó lapjaira (167. o.) marad.

Végezetül néhány tárgyi észrevétel, helyreigazítani való. Csak megemlíteném, hogy a szlovákiai településszerkezet földrajzi alapjainak leírásánál és jellemzésénél (36-38. o.) szerintem nagyon érződött a problémakör tárgyalásánál egy - ugyan nem igazán friss, mégis frappáns - földrajzi megoldás használatának a hiánya; az 1980-as években kidolgozott Lukniš-féle térszerkezeti modellre gondolok, az ország funkcionális régiótípusainak meghatározására (Lukniš 1985). A szerző által itt hivatkozott és használt forrás (Očovský-Bezák-Podolák 1996) frissebb ugyan, azonban, azt hiszem, nem túlzás azt állítani, hogy ezen a téren a szlovák településföldrajzban (majdnem) minden „Lukniš köpönyegéből” bújt elö; nyilván az sem előzmények nélkül való, persze. A Lukniš-féle szintézisnek vannak gyenge pontjai és sok szempontból valóban elhaladt már fölötte az idő, de kiindulási alapnak Szlovákia térszerkezetének megismeréséhez, az ország „működésének” megértéséhez, ma is kiválóan megfelel. A szerző által használt forrás - s így maga Mezei is - aztán később hivatkozik is a szlovák településföldrajz neves alakjára. Négyosztatú 
térszerkezeti modelljének alkalmazása a munka jelzett részében sokat segített volna a földrajzi összefüggések pontosabb bemutatásában és megértetésében.

Az 52. oldalon szereplő 18. táblázatban a szerző a már említett 1861-es Memorandum-terület és mai a Szlovákia összesített adatait veti össze, ami önmagában jó ötlet, de a levonható következtetésekkel az eltérő területek miatt azért csínján kell bánni.

Mezei szerint „A kommunizmus negyven éve sok vonatkozásban hátrányos volt Pozsonyra, mint városra nézve is" (64. o., k. t.). Ehhez csak annyit füznék hozzá, hogy - szerintem - még több vonatkozásban, éppenséggel: nem. A szerző részletesen kifejtett megállapításaival egyébként egyetértek, de egyrészt a negyven éven belül azért különböztek bizonyos korszakok, másrészt, noha valóban szenvedett el a város történelmileg, tudjuk: „szükségszerü” - károkat és torzulásokat a diktatúra negyven éve alatt, az összegző mérlegvonás nem tagadhatja el, hogy népességében, szerepköreiben és helyzetében végtére is egyértelmüen nőtt, gyarapodott és emelkedett.

Egy, a 68. oldalon szereplö mondatban az első szlovákiai atomerőmü kapcsán említett Jaslovské Bohunice Nyitrától északra van pozícionálva, ami szük értelemben ugyan igaz, de a várostól légvonalban mintegy $30 \mathrm{~km}-\mathrm{re}$, nyugat-északnyugatra, a Vág folyó túlpartján fekvő település elhelyezkedése kapcsán mégiscsak inkább azt szokás kiemelni, hogy Nagyszombattól csupán alig 15 km-re északra található. A 89. oldalon a városodás mértékét az egyes járásokban bemutató 12. ábra jelmagyarázatához elkelne némi egyértelmüsítés a \%-ok puszta jelzése mellett, illetve sem a címböl, sem a hivatkozott forrásból nem derül ki, melyik évre vonatkoznak a feldolgozott adatok. Ugyanezen oldalon, a térképen is ábrázolt jelenség leírásánál, a járásoknak városi népesség aránya szerinti csoportosításánál elsikkad, hogy a megoszlásnak konkrét településföldrajzi, szerkezetbeli okai is vannak; például a hegyvidéki szórványtelepülés-formák elhelyezkedése vagy a domborzati adottságok. Szintén ehhez a kérdéshez kapcsolódik, hogy az „,aprófalvas környezet földrajzi elterjedtségének" bemutatására talán nem a kerületi szintủ adatok összehasonlítása a legalkalmasabb, ahogy az a 44. oldalon található 14. táblázatban látható, mert ezen a szinten azért néhány fontos településföldrajzi összefüggés már elmosódik.

Egyéb apróságok. A 103. oldalon szerepel egy mondat, miszerint: „Teljesen hiányzik viszont az évszázadokon keresztül létfontosságú útvonal kiépítettsége az Árva-Besztercebánya-Budapest vonalon" [k. t.]. Meghökkentő állítás. Az E77-es bizonyos szakaszaira nyilván jogosan lehetne panaszkodni, s Garam és a Vág völgye közti útszakasz, a Donovaly-hágó, az Alacsony-Tátrában télen valóban meglehetősen veszélyes, de, hogy teljesen kiépítetlen lenne a szlovákiai része ennek az északdéli tengelynek, tévedés. A 118. oldalon egy mondatban Pozsonyt és Bécset is a szembenálló világrendszerek „,perifériájára kerültként” jellemezni a hidegháború éveiben. Szerintem ez árnyalandó; még ha egy átvett idézetről is van szó, legalábbis jelezni kéne, hogy átvitt értelemben azért, különösen Bécs, például a nagyhatalmak közötti tárgyalások csaknem intézményesült helyszíneként, vagy éppen az ENSZ bizonyos intézményeinek központjaként, aligha számíthatott perifériának. Pozsony gazdasági jellemzésénél, a 122. oldalon, a VW 1991-es ,idetelepítése” kapcsán a szövegkörnyezetből nem világlik ki, hogy nem egy zöldmezős, hanem még az előző 
rendszerben beindított autóipari fejlesztésbe való beruházásról volt szó. Ugyanez a helyzet egy Érsekújvárt leíró mondattal a 126. oldalon; az izzógyártásnak ott már voltak előzményei (Elektrosvit), nem pusztán az (új) autógyárak „hatására épült fel” a német Osram üzeme. A nyitrai kerület gazdaságföldrajzi jellemzésénél a 125-126. oldalakon fölöttébb furcsa a mohi atomerőmű meg nem említése! Végül megjegyezném, hogy a Győr és Esztergom közötti Duna-szakasz szlovákiai oldalán fekvő települések mátyusföldiként való jellemzése (143. o.) több mint vitatott. A bizonytalan helyzetü, de a Csallóköztől mégiscsak egészen biztosan északra fekvő Mátyusföld keleti határát vagy a Vág folyó Gúta fölötti szakasza mentén, vagy legfeljebb Érsekújvár környékéig terjedően szokták keresni. A szlovákiai oldal Vág- és a Garamtorkolat közti, határozottan rurális jellegü vidékének települései a regionalizálás taxonómiai rendszereinek szemszögéből is névtelenül lebegnek a semmiben.

Amit a munkából feltétlenül kiemelnék, azok a következő összefoglaló, értékelő gondolatok. „,...a szlovák honfoglalás műve sikeresen teljesült. Az új ország súlyponti városai és a hajdani Magyarország Felvidéken elhelyezkedő súlyponti városai teljesen új mintázatot képviselnek. A földrajzi eltérés - a délre futó folyók középső és északi völgyeiben helyezkednek el azok a városok, amelyek az új államban központi szerepet kapnak - tartalmi eltérést takar. Az 1918 után fejlődésnek indult, szándékos fejlesztéssel az első szakaszban politikai (1918-1945), a másodikban ipari (1945-1989), a harmadik ... (1989-) szakaszban szolgáltató, üzleti, a modernizációt képviselö, magasan képzett szakemberekkel telített városok alkotják az új ország új városszerkezetét. Ez az új városhálózat gyakorol vonzást a távolabb fekvő, elsősorban a hosszú déli határ mentén fekvő, jóval fejletlenebb, gazdasági szerepüket illetően sokadlagos fontosságú városokra. A jelenlegi súlyponti városok biztosítják a vonzást, az emberek, a munkavállalók, a tőke áramlási irányát.” Ennek az „új városszerkezeti ívnek” a két végpontja, Pozsony és Kassa, „...részben indítói, szervezői, vonzást kibocsátó központjai az új városszerkezetnek, részben magukban rejtik és gyakorolják is már saját vonzerejük más országok felé sugárzását” (57. o.).

Szlovákia napjainkra kialakult városhálózatának általános jellemzését tekintve Mezei értékelése véleményem szerint helytálló; az általa levont, s az olvasói által levonható következtetések is hasznosnak minősíthetők a határ menti önkormányzati-, civil- és településközi együttmüködések hátterének, mozgatórugóinak, lehetőségeinek és akadályainak megítélésében. Talán kevésbé hangsúlyos e településszerkezet „erejének” „súlyának” megfordíthatatlan jellegének bemutatása. Az a szlovákiai szlovák nyelvü szakirodalomból, az ottani politikai, közéleti és tudományos vitákból leszürhető tanulság, hogy a szlovákiai oldal kutatói ezt a településszerkezetet túlnyomórészt afféle ,eleve elrendeltetettnek”, megváltoztathatatlannak és alternatíva nélkülinek fogják föl.

A fentieket összefoglalva, elmondható: egy nagy ívű munka eredményét tarthatjuk kézben a szerző lelkiismeretesen véghezvitt kutatásai, valamint a somorjai Fórum Kisebbségkutató Intézet és a pécsi RKK együttmüködésének jóvoltából. Egy sokrétü, tárgyilagos közelítéssel és érzékeny odafigyeléssel kidolgozott, több, szerteágazó szálba szétfutó elemzésnek a határ menti együttműködés szereplőinek 
körében - gyakorlati munkájuk során - remélhetőleg sokféleképpen hasznosítható gyümölcseit. Már csak ezért sem hagyhatom említés nélkül a könyv „,váratlan/varratlan” befejezését: nagyon hiányzik egy összegző áttekintés a végéröl!

\section{Irodalom}

Lukniš, M. (1985) Regionálne členenie Slovenskej socialistickej republiky z hladiska jej racionálneho rozvoja. - Geografiický časopis. 2-3. 137-163. o.

Očovský, Š.-Bezák, A.-Podolák, P. (1996) Siedlungstruktur und Zentrenentwicklung in der Slowakischen Republik. - Beiträge zur Regionalen Geogrphie. 39. Leibnitz -Institute für Länderkunde, Leipzig. 
$=$ 